\title{
Influence of 1-phenoxy-2-propanol on blood profile of common carp
}

\author{
Ewa Czerniak, Piotr Gomułka, Jakub Dągowski \\ University of Warmia and Mazury in Olsztyn, Faculty of Environmental Sciences, \\ Department of Ichthyology, Olsztyn, Poland \\ Received January 24, 2017 \\ Accepted May 31, 2017
}

\begin{abstract}
1-phenoxy-2-propanol is a common and effective anaesthetic for aquatic organisms such as bivalves and pulmonates. However, there are no data regarding its influence on fish organisms. In the present study the anaesthetic efficacy of 1-phenoxy-2-propanol and its influence on biochemical and haematological blood indices of juvenile common carp were studied. For blood profile test, fish were divided into four groups $(n=10)$. The haematological and blood biochemical profiles of common carp were evaluated $10 \mathrm{~min}$ and $24 \mathrm{~h}$ after anaesthesia with 1-phenoxy-2-propanol $\left(400 \mathrm{mg} \cdot \mathrm{dm}^{-3}\right)$ and compared to non-anaesthetized control groups. Significant changes $(P<0.05)$ in red blood cell indices and in white blood cell count were found as well. Increased concentrations of glucose, ammonia and inorganic phosphates indicate that stress reaction occurred. No changes in total protein, globulin, triacylglycerols, alkaline phosphatase, aspartate aminotransferase and calcium were found. Although exposure to 1-phenoxy-2-propanol caused a moderate, temporary stress response in examined fish, we can state that 1-phenoxy-2propanol can be used as an effective anaesthetic for common carp.
\end{abstract}

Propylene phenoxytol, anaesthesia, biochemistry, haematology, Cyprinus carpio

The beneficial influence of anaesthetics and analgesics has been known for centuries, however, they have been used in fish anaesthesia for a particularly short period of time. First reports about anaesthetizing fish refer to anaesthesia of salmon and steelhead trout with carbon dioxide (Fish 1943). From this time several different chemicals such as MS222 (Randall 1962), 2-phenoxyethanol (Sehedev et al. 1963), quinaldine (Schoettger and Steucke 1970), benzocaine (Oswald 1978), etomidate (Amend 1982), metomidate (Stoskopf and Arnold 1985), clove oil (Hisaka 1985) and propofol (Fleming et al. 2003) were tested as anaesthetics for fish. However, because of marked anatomical, physiological and behavioral variations, there are still no anaesthetics which can be used for all fish species. So it is very important to seek new, potentially better anaesthetics.

1-phenoxy-2-propanol (PP) is the analogue of 2-phenoxyethanol (2PE). It is a glycol ether forming a clear, colourless liquid at room temperature. Although relatively hydrophobic, it can be dissolved in water, however, to a lower extent compared to $2 \mathrm{PE}$. The solubility of $2 \mathrm{PE}$ and PP are 27 and $11 \mathrm{~g} \cdot \mathrm{dm}^{-3}$, respectively. 1-phenoxy-2-propanol is widely used in the study of invertebrates. It has been proved that PP can be used to relax or anaesthetize pulmonates (Runham et al. 1965), bivalves (Owen 1955; Norton et al. 1996; Norton et al. 2000) and nudibranchs (Holman et al. 2002; Redondo and Murray 2005; Wyeth and Willows 2006b). It was also used as an anaesthetic for rats (Saghir et al. 2003). However, although it was found to be effective, its anaesthetic action has not been thoroughly investigated. No data addressing its anaesthetic efficacy or toxicity to fish are available.

The aim of this study was to assess the anaesthetic potency of PP and its influence on biochemical and haematological blood indices of common carp.

Address for correspondence:

Ewa Czerniak

Department of Ichthyology

University of Warmia and Mazury

Oczapowskiego 5, 10-719 Olsztyn, Poland

Phone: (+48) 696565272

E-mail: ewa czerniak@yahoo.com

http://actavet.vfu.cz/ 


\section{Materials and Methods}

Fish

The experiment was carried on young carp $(\mathrm{n}=40)$ of $107 \pm 20.9 \mathrm{~g}$ of weight and $190 \pm 11.9 \mathrm{~cm}$ in total length. Fish were supplied by local Fish Farm Ostróda, Poland. Fish were acclimated for two weeks before experiment in $0.3 \mathrm{~m}^{3}$ tanks and fed commercial pellet feed. The water temperature during acclimation and the experiment was $19.5 \pm 0.5^{\circ} \mathrm{C}$.

Anaesthetic

For biochemical and haematological tests, 1-phenoxy-2-propanol (PP) supplied by Sigma Aldrich (USA) was used. Before the experiment, a working solution of PP in ethyl alcohol $\left(50 \mathrm{~g} \cdot \mathrm{dm}^{-3}\right)$ was prepared.

\section{Exposure}

The procedure proposed by Velíšek and Svobodová (2004 a,b) and Velíšek et al. (2006) was applied. Fish were randomly caught from the tank and individually subjected to one of the following procedures. Control fish (CF) $(n=10)$ were blood sampled immediately (within less than 2 min, without anaesthesia) after the catch. Treatment 1 fish (T1) $(\mathrm{n}=10)$ were exposed to water solution of $400 \mathrm{mg} \cdot \mathrm{dm}^{-3}$ of PP for $10 \mathrm{~min}$, and blood was sampled immediately after exposure; treatment 2 fish $(\mathrm{T} 2)(\mathrm{n}=10)$ were exposed to PP as above and then moved to the tank $\left(0.3 \mathrm{~m}^{3}\right.$ of volume $)$ filled with anaesthetic-free water for recovery. Blood was sampled $24 \mathrm{~h}$ after exposure. Stress-exposed control fish $(\mathrm{SEC})(\mathrm{n}=10)$ were caught from the rearing tank and placed in an exposure box filled with anaesthetic-free water for $10 \mathrm{~min}$ and then moved to a $0.3 \mathrm{~m}^{3}$ tank for recovery. Blood was sampled after $24 \mathrm{~h}$. Both T2 and SEC fish were blood-sampled without anaesthesia. The exposure was done in a $12 \mathrm{dm}^{3}$ polypropylene box. The PP solution was aerated mechanically. Bath temperature was the same as in the rearing tank water.

\section{Blood analysis}

Blood was sampled from caudal vessels by a syringe covered with heparin lithium salt. Approximately $0.8 \mathrm{ml}$ of the blood was centrifuged in StatSpin centrifuge at 12,000 $\mathrm{g}$ for $30 \mathrm{~s}$. Blood plasma was collected for biochemical analysis and immediately frozen at $-20{ }^{\circ} \mathrm{C}$. The rest of collected blood was used for blood smear preparation ( 2 smears per each fish) and determination of haematological indices. After blood sampling, fish were placed in excessive propofol solution $\left(20 \mathrm{mg} \cdot \mathrm{dm}^{-3}\right)$. Following the arrest of an opercular movement, fish brain was destroyed with sharp scissors and the length (LC) and weight measurements were taken.

Haematological indices were determined according to standard methods given in Unified Methods for Haematological Examination of Fish (Svobodova et al. 1986) and covered: erythrocyte count (RBC), haemoglobin concentration $(\mathrm{Hb})$, haematocrit $(\mathrm{PCV})$, mean erythrocyte volume $(\mathrm{MCV})$, mean corpuscular haemoglobin concentration (MCHC), mean corpuscular haemoglobin (MCH), leukocyte count (WBC) and the differential leukocyte count (leukogram).

Plasma samples were analyzed with Catalyst Dx Chemistry Analyzer (Idexx Lab., USA). Analysis of biochemical indices included: inorganic phosphates (PHOS), calcium (Ca), total protein (TP), albumin (ALB) and globulin (GLOB), ammonia $\left(\mathrm{NH}_{3}\right)$, triacylglycerols (TRIG), glucose (GLU), aspartate aminotransferase (AST), and alkaline phosphatase (ALKP). Each plasma sample was thawed only once at room temperature and all the above listed indices were determined at one run of the chemistry analyser.

Statistical analysis

Statistica StatSoft 12.0 software was used for statistical analysis. To test normality and variance homogeneity, Shapiro-Wilk's and Leven's tests, respectively, were used. Differences between groups were tested with univariate ANOVA and nonparametric Kruskall-Wallis tests. The differences were considered as significant at $P \leq 0.05$.

\section{Results}

No mortalities were observed $24 \mathrm{~h}$ following anaesthesia. The exposure of fish to PP resulted in significant $(P<0.05)$ changes in red blood indices (Table 1). The RBC values were significantly higher in both anaesthetized groups as well as in SEC fish compared to CF. Significantly higher values of PCV were determined in T1 fish compared to CF. However, they returned to the initial values over the next $24 \mathrm{~h}$. The $\mathrm{Hb}$ values were significantly lower $24 \mathrm{~h}$ after exposure in $\mathrm{T} 2$ and SEC fish. The MCV, MCHC, and $\mathrm{MCH}$ values were significantly decreased in both anaesthetized groups as well as in the SEC group. 
Table 1. Changes in haematological blood indices of common carp during PP anaesthesia.

\begin{tabular}{|c|c|c|c|c|}
\hline \multirow{2}{*}{ Indices } & \multicolumn{4}{|c|}{ Treatment } \\
\hline & $\mathrm{CF}$ & $\mathrm{T} 1$ & SEC & $\mathrm{T} 2$ \\
\hline $\mathrm{RBC}\left[\mathrm{T} \cdot \mathrm{dm}^{-3}\right]$ & $0.97 \pm 0.26^{\mathrm{a}}$ & $1.53 \pm 0.22^{\mathrm{b}}$ & $1.27 \pm 0.32$ & $1.55 \pm 0.3^{\mathrm{b}}$ \\
\hline PVC & $0.29 \pm 0.04^{\mathrm{a}}$ & $0.37 \pm 0.02^{\mathrm{b}}$ & $0.32 \pm 0.02^{\mathrm{a}}$ & $0.3 \pm 0.02^{\mathrm{a}}$ \\
\hline $\mathrm{Hb}\left[\mathrm{g} \cdot \mathrm{dm}^{-3}\right]$ & $83.54 \pm 6.74^{\mathrm{a}}$ & $85.98 \pm 2.80^{\mathrm{a}}$ & $61.92 \pm 5.64^{b}$ & $63.98 \pm 8.7^{b}$ \\
\hline $\operatorname{MCV}[\mathrm{fl}]$ & $327.6 \pm 77.8^{\mathrm{a}}$ & $243.53 \pm 48.86^{\mathrm{b}}$ & $263.88 \pm 74.19^{\mathrm{b}}$ & $201.71 \pm 50.29^{b}$ \\
\hline $\mathrm{MCHC}\left[\mathrm{g} \cdot \mathrm{dm}^{-3}\right]$ & $277.7 \pm 20.7^{\mathrm{a}}$ & $233.91 \pm 14.60^{\mathrm{b}}$ & $196.94 \pm 18.03^{b}$ & $211.95 \pm 18.32^{b}$ \\
\hline $\mathrm{MCH}[\mathrm{pg}]$ & $91.6 \pm 25.8^{\mathrm{a}}$ & $57.54 \pm 10.05^{b}$ & $52.69 \pm 19.23^{b}$ & $43.12 \pm 13.89^{b}$ \\
\hline $\mathrm{WBC}\left[\mathrm{g} \cdot \mathrm{dm}^{-3}\right]$ & $78.25 \pm 9.13^{\mathrm{a}}$ & $52.75 \pm 7.94^{\mathrm{b}}$ & $44.00 \pm 5.91^{\mathrm{b}}$ & $56.75 \pm 16.87^{b}$ \\
\hline
\end{tabular}

Groups with different alphabetic superscripts differ significantly at $P<0.05$ (ANOVA)

$\mathrm{RBC}$ - red blood cell, $\mathrm{PCV}$ - haematocrit, $\mathrm{Hb}$ - haemoglobin, $\mathrm{MCV}$ - mean corpuscular volume, $\mathrm{MCHC}-$ mean corpuscular haemoglobin concentration, $\mathrm{MCH}-$ mean corpuscular haemoglobin, WBC - white blood cell, $\mathrm{CF}$ - control fish, SEC - stress exposed control fish, T1 - treatment 1 fish, T2 - treatment 2 fish, PP - 1-phenoxy-2-propanol

A significant decrease of WBC was noticed in both anaesthetized groups as well as in SEC fish compared to CF. It was mainly due to the decrease of the lymphocyte count (Table 2).

Table 2. Changes in differential leukocyte counts in common carp during PP anaesthesia.

\begin{tabular}{lccrr}
\hline Indices & \multicolumn{4}{c}{ Treatment } \\
\cline { 2 - 5 } & CF & T1 & SEC & T2 \\
\hline $\begin{array}{l}\text { Lymphocytes }\left[\mathrm{G} \cdot \mathrm{dm}^{-3}\right] \\
\begin{array}{l}\text { Segmented granulocytes } \\
{\left[\mathrm{G} \cdot \mathrm{dm}^{-3}\right]}\end{array}\end{array}$ & $33.49 \pm 7.16^{\mathrm{a}}$ & $20.31 \pm 6.59^{\mathrm{b}}$ & $17.38 \pm 6.22^{\mathrm{b}}$ & $22.08 \pm 7.59^{\mathrm{b}}$ \\
$\begin{array}{l}\text { Banded granulocytes } \\
{\left[\mathrm{G} \cdot \mathrm{dm}^{-3}\right]}\end{array}$ & $1.29 \pm 0.36^{\mathrm{a}}$ & $1.13 \pm 0.59^{\mathrm{a}}$ & $1.08 \pm 0.52^{\mathrm{a}}$ & $1.45 \pm 0.42^{\mathrm{a}}$ \\
$\begin{array}{l}\text { Developmental phases }- \\
\text { myeloid sequence }\left[\mathrm{G} \cdot \mathrm{dm}^{-3}\right]\end{array}$ & $2.20 \pm 1.11^{\mathrm{a}}$ & $2.18 \pm 1.50^{\mathrm{a}}$ & $1.96 \pm 1.34^{\mathrm{a}}$ & $2.24 \pm 1.79^{\mathrm{a}}$ \\
\hline
\end{tabular}

Groups with different alphabetic superscripts differ significantly at $P<0.05$ (ANOVA)

$\mathrm{CF}$ - control fish, SEC - stress exposed control fish, T1 - treatment 1 fish, T2 - treatment 2 fish, PP - 1-phenoxy2-propanol

After a 10 min exposure to PP, no changes in total protein blood plasma and globulin concentration were found. However, PP anaesthesia caused a significant increase of albumin concentration $24 \mathrm{~h}$ following exposure in T1, T2, and SEC fish.

The significant increase of glucose concentration was observed in T1 and T2 fish. Also SEC fish showed elevated blood plasma glucose concentration (Fig. 1a). Triacylglycerol concentrations were not affected and ranged between 1.66 and $1.99 \mathrm{mmol} \cdot \mathrm{dm}^{-3}$.

A significant increase of inorganic phosphate concentration was observed in T1 fish, however, it was restored within $24 \mathrm{~h}$ after exposure (Fig. 1b). Phosphate was also increased in SEC fish, however, it was not significantly different compared to control.

Anaesthesia with PP caused a significant increase of ammonia concentration in fish blood, however, it was restored to initial values within $24 \mathrm{~h}$ (Fig. 1c).

No changes were observed in Ca blood concentration, as well as in ALKP activity.

Detailed effects of PP anaesthesia on the blood plasma biochemical profile of carp are given in Table 3 . 

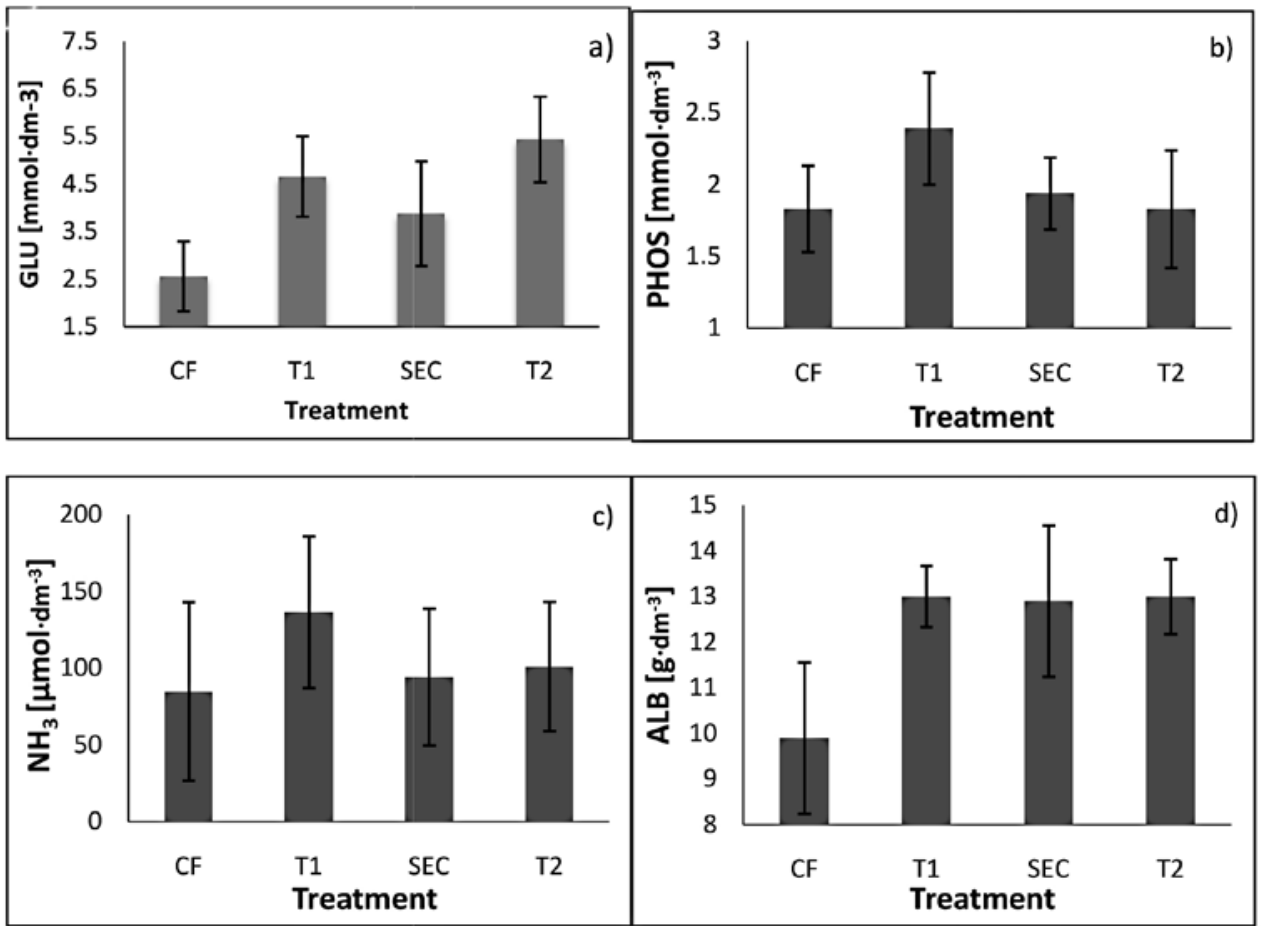

Fig. 1. Blood indices of common carp exposed to 1-phenoxy-2propanol anaesthesia GLU - glucose, PHOS - inorganic phosphates, NH3- ammonia, ALB - albumin

Table 3. Changes in biochemical blood indices of common carp during PP anaesthesia.

\begin{tabular}{lrrrr}
\hline Indices & \multicolumn{4}{c}{ Treatment } \\
\cline { 2 - 5 } & \multicolumn{1}{c}{ CF } & \multicolumn{1}{c}{ T1 } & \multicolumn{1}{c}{ SEC } & T2 \\
\hline TP $\left[\mathrm{g} \cdot \mathrm{dm}^{-3}\right]$ & $27.50 \pm 2.07^{\mathrm{a}}$ & $28.70 \pm 2.58^{\mathrm{a}}$ & $29.30 \pm 3.56^{\mathrm{a}}$ & $29.40 \pm 2.46^{\mathrm{a}}$ \\
$\mathrm{ALB}\left[\mathrm{g} \cdot \mathrm{dm}^{-3}\right]$ & $9.90 \pm 1.66^{\mathrm{a}}$ & $13.00 \pm 0.67^{\mathrm{b}}$ & $12.90 \pm 1.66^{\mathrm{b}}$ & $13.00 \pm 0.82^{\mathrm{b}}$ \\
$\mathrm{GLOB}\left[\mathrm{g} \cdot \mathrm{dm}^{-3}\right]$ & $17.60 \pm 1.51^{\mathrm{a}}$ & $15.70 \pm 2.11^{\mathrm{b}}$ & $16.40 \pm 2.22^{\mathrm{a}}$ & $16.40 \pm 2.07^{\mathrm{a}}$ \\
$\mathrm{ALKP}\left[\mu \mathrm{kat}^{\mathrm{a}} \mathrm{dm}^{-3}\right]$ & $0.29 \pm 0.09^{\mathrm{a}}$ & $0.21 \pm 0.08^{\mathrm{a}}$ & $0.27 \pm 0.12^{\mathrm{a}}$ & $0.26 \pm 0.12^{\mathrm{a}}$ \\
TRIG $\left[\mathrm{mmol} \cdot \mathrm{dm}^{-3}\right]$ & $1.66 \pm 0.36^{\mathrm{a}}$ & $1.80 \pm 0.54^{\mathrm{a}}$ & $1.99 \pm 0.67^{\mathrm{a}}$ & $1.72 \pm 0.62^{\mathrm{a}}$ \\
$\mathrm{Ca}\left[\mathrm{mmol} \cdot \mathrm{dm}^{-3}\right]$ & $2.04 \pm 0.09^{\mathrm{a}}$ & $2.00 \pm 0.17^{\mathrm{a}}$ & $2.04 \pm 0.15^{\mathrm{a}}$ & $2.08 \pm 0.20^{\mathrm{a}}$
\end{tabular}

Groups with different alphabetic superscripts differ significantly at $P<0.05$ (ANOVA)

TP - total protein, GLOB - globulin, ALB - albumin, TRIG - triacylglycerols, ALKP - alkaline phosphatase, AST - aspartate aminotransferase, $\mathrm{Ca}$ - calcium, CF - control fish, SEC - stress exposed control fish, T1 - treatment 1 fish, T2 - treatment 2 fish, PP - 1-phenoxy-2-propanol

\section{Discussion}

Analysis of the haematological profile is an important tool that can be used as an effective and sensitive index to monitor physiological and pathological changes occurring in the fish organism. However, normal values of haematological indices differ greatly from one species to another (Landis et al. 2005; Antache et al. 2014). According to Caldwell 
and Hinshow (1994) and Iwama (1998), sudden increase in the number of circulating erythrocytes as well as increase of PCV and $\mathrm{Hb}$ concentrations may be due to the release of red blood cells from the spleen. The PP anaesthesia resulted in a significant, almost two-fold increase of RBC count in anaesthetized fish. This increased level was maintained for $24 \mathrm{~h}$. However, even higher erythrocyte count was noted in SEC fish compared to the T2 group. Significant decrease of MCV was also observed in anaesthetized fish compared to the control group. However, the mean MCV values were relatively higher than the ones reported by other authors (Velíšek et al. 2007a). Also, the significant increase of Ht level immediately after anaesthesia $(0.37 \pm 0.02)$ could occur due to the high level of RBC. However, it returned to the control level $(0.28 \pm 0.02)$ within $24 \mathrm{~h}$ after exposure to PP.

It is believed that leukopenia commonly occurs during the physiological response to acute stressors in fish (Wedemayer 1970; McLeay and Gordon 1977; Wedemeyer et al. 1983). Increased apoptosis of lymphocytes results from a rise of the cortisol level during a stress reaction (Wyets et al. 1998). The PP anaesthesia caused a significant decrease of the lymphocyte count in exposed fish. On the other hand, Velís ek et al. (2007a; $2007 b$ ) did not observe any changes in rainbow trout, carp, or in sheatfish exposed to $2 \mathrm{PE}$.

Analysis of the biochemical blood profile is one of the most valuable methods available to modern diagnostics and can provide important information about the effects of anaesthetics on the fish organism (Iwama et al. 1989; Anver Celik 2004; Kristan et al. 2012). Under stress, the body of the fish emits immediate responses recognized as primary and secondary responses. The primary response is the perception of an altered state by the central nervous system (CNS) and the release of the stress hormones cortisol and catecholamines (adrenaline and epinephrine) into the bloodstream by the endocrine system (Randall and Perry 1992). Secondary responses occur as a consequence of released stress hormones (Barton and Iwama 1991) and are revealed e.g. as an increase of glucose and ammonia contents and as a decrease of the total protein concentration. Jahanbakhishi et al. (2012) report that an increased plasma glucose content during stress reflects the release of catecholamines and glucocorticoids from adrenal tissues of fish.

Blood plasma glucose concentration increased almost two-fold in fish of groups T1 $\left(4.66 \pm 0.85 \mathrm{mmol} \cdot \mathrm{dm}^{-3}\right)$ and $\mathrm{T} 2\left(5.44 \pm 0.90 \mathrm{mmol} \cdot \mathrm{dm}^{-3}\right)$ in comparison to group CF $\left(2.56 \pm 0.73 \mathrm{mmol} \cdot \mathrm{dm}^{-3}\right)$. This indicates that the treatment used caused acute stress in experimental carp. The increase of glucose concentration was also observed in the gilthead bream (Ortuño et al. 2002), kelp grouper (Park et al. 2008), rainbow trout (Velíšsek et al. 2011), and Senegalese sole (Weber et al. 2011) exposed to 2PE. However, Velíšsek et al. (2004) did not observe any changes in glucose concentration in carp anaesthetized with 2-PE.

It is said that under prolonged stress, fish can mobilize fat stores and protein to meet an increased demand for energy necessary to sustain their increased physical activity (Iwama et al. 1986; Govindon et al. 1994). No differences in TRIG and TP contents were found between controls and fish exposed to PP in our experiment. However, a significant increase of ALB concentration was observed in all exposed fish. Velíšek and Svobodová $(2004 a, b)$ did not observe any changes in TP contents in rainbow trout and carp but they also found changes in ALB concentration in blood of rainbow trout exposed to 2PE. Blood analysis revealed increased concentration of ALB in sheatfish exposed to 2PE (Velíšek et al. 2007b).

It has been proved that respiratory acidosis is followed by an increase of phosphate and calcium concentrations and ammonia autointoxication (Ghosh and Joshi 2008; Gomułka et al. 2015). Increased ammonia content can also occur due to deamination of amino acids, especially glutamate, during extended energy production (Smutná et al. 2002). During our experiment, a significant increase of ammonia and phosphate concentrations was observed in T1 fish compared to controls. However, both ammonia and phosphate returned 
to their initial concentrations within $24 \mathrm{~h}$ after exposure to PP. No changes in PHOS and $\mathrm{NH}_{3}$ concentrations were found in the rainbow trout and common carp (Velíšek and Svobodová 2004a,b; Velíšek et al. 2011), sheatfish (Velíšek et al. 2007a) and perch (Velíšek et al. 2009) exposed to 2PE.

Our previous results (in press) showed that PP can be used as an efficient anaesthetic for common carp. However, the biochemical and haematological blood profile of common carp exposed to PP indicates that moderate, temporary stress occurred in fish exposed to PP. Moreover, changes caused by PP appear to be more severe than those reported in carp by Velíšek and Svobodová (2004a) as caused by 2PE. Thus, we recommend special care during the anaesthetizing of common carp with PP. Further research is needed to develop safe and effective procedure of anaesthesia with PP in fish.

\section{References}

Amend DF, Goven BA, Elliot DG 1982: Etomidate: effective dosages for a new fish anesthetic. Trans Am Fish Soc 111: $337-341$

Antache A, Cristea V, Grecu I, Dediu L, Cretu M, Bocioc E, Petrea SM 2014: Effects of dietary supplementation at Nile tilapia with Thymus vulgaris, Trigonela foenum graceum and Azadirachta indica on welfare status. Bull Univ Agric Sci Vet Med Cluj-Napoca Anim Sci Biotech 71: 115-122

Anver Celik E 2004: Blood chemistry (electrolytes, lipoprotein and enzymes) values of black scorpion fish (Scorpaena porcus 1758) in the Dardanelles. Turkey J Biol Sci 4: 716-719

Barton BA, Iwama GK 1991: Physiological changes in fish from stress in aquaculture with emphasis on the response and effects of corticosteroids. Annu Rev Fish Diseases 1: 3-26

Caldwell CA, Hinshaw J 1994: Physiological and haematological responses in rainbow trout subjected to supplemental dissolved oxygen in fish culture. Aquaculture 126: 183-193

Fish FF 1943: The anaesthesia of fish by high carbon dioxide concentrations. Trans Am Fish Soc 72: 25-29

Fleming GJ, Heard DJ, Floyd RF, Riggs A 2003: Evaluation of propofol and metomidate-ketamine for shortterm immobilization of Gulf of Mexico sturgeon (Acipenser oxyrinchus de soti). J Zoo Wild Med 34: 153-158

Ghosh AK, Joshi SR 2008: Disorders of calcium, phosphorus and magnesium metabolism. J Assoc Physician India 56: 613-621

Gomułka P, Czerniak E, Dągowski J, Luczyński M, Szczerbowski A, Szkudlarek M 2015: The effects of propofol and carbon dioxide on acid-base balance in Siberian sturgeon. Polish J Vet Sc 18: 267-272

Govindon US, Jacob L, Devika R 1994: Toxicity and metabolic changes in Gambusia affins exposed to phosphamidon. J Ecotoxical Eviron Monit 4: 1-6

Hisaka Y, Takase K, Ogasawara T, Ogasawara S. 1985: Anesthesia and recovery with tricaine methanesulphonate, eugenol and thiopental sodium in the carp, Cyprinus carpio. Jpn J Vet Sci 48: 341-351

Holman G, Hanein Y, Wyeth RC, Willows AOD, Denton DD, Bohringer KF 2002: Silicon micro-needles with flexible interconnections. In: Second international IEEE-EMBS special topic conference on microtechnologies in medicine and biology, pp 255-260

Iwama GK, Greer GL, Randall DJ, 1986: Changes in selected hematological parameters in juvenile Chinook salmon subjected to a bacterial challenge and a toxicant. J Fish Biol 28: 563-572

Iwama GK, Thomas PT, Forsyth RB, Vijayan MM 1998: Heat shock protein expression in fish. Rev Fish Biol Fish 8: $35-56$

Jahankbakhshi A, Baghfalaki M, Imanpour MR, Nodeh AJ, Shaluei F 2012: Effects of different concentrations of 2-phenoxyethanol on primay and secondary stress responses in Persian sturgeon, Acipenser persicus. J of Appl Ichthyol 29: 499-502

Kristan J, Stara A, Turek J, Policar T, Velisek J 2012: Comparison of the effects of four anaesthetics on haematological and blood biochemical profiles in pikeperch (Sander lucioperka L.). Neuroendocrinology Letters 33: 66-71

McLeay DJ, Gordon MR 1977: Leucocrit: A simple hematological technique for measuring acute stress in salmonids fish including stressful concentration of pulpmill effluent. J Fish Res Board Canada 34: 2164-2175

Norton JH, Dashorst M, Lanksy TM, Mayer RJ 1996: An evaluation of some relaxants for use with pearl oysters. Aquaculture 144: 39-52

Norton JH, Lucas JS, Turner I, Mayer RJ, Newnham R 2000: Approaches to improve cultured pearl formation in Pinctada margaritifera through use of relaxation, antiseptic application and incision closure during bead insertion. Aquaculture 184: 1-17

Ortuño J, Esteban MA, Meseguer J 2002: Effects of phenoxyethanol on the innate immune system of gilthead seabream (Sparus aurata L.) exposed to crowding stress. Vet Immunology and Immunopathol 89: 29-36 
Oswald RL 1978: Injection anaesthesia for experimental studies in fish. Comp Biochem Physiol 60C: 19-26

Owen G 1955: Use of propylene phenoxetol as a relaxing agent. Nature 175: 434

Park MO, Hur WJ, Im SY, Seol DW, Lee J, Park IS 2008: Anaesthetic efficacy and physiological responses to clove-anaesthetized lelp grouper Epinephelus bruneus. Aquaculture Research 39: 877-884

Randall DJ, 1962: Effect of anaesthetic on the heart and respiration of a teleost fish. Nature 195: 506

Randall DJ, Perry SF 1992: Catecholamines, In: Hoar WS, Randall DJ, Farrell AP (Eds), Fish Physiology - The Cardivascular System. Vol XIIB. Academic Press. New York, pp 255-300

Redondo RL, Murray JA 2005: Pedal neuron 3 serves a significantrole in effecting turning during crawling by the marine slug Tritonia diomedea. J Comp Physiol A 191: 435-444

Runhum NW, Isarankura K, Smith BJ 1965: Methods for narcotizing and anaesthetizing gastropods. Malacologia 2: $231-238$

Saghir SA, Brzak KA, Bartels MJ 2003: Oral absorption, metabolism and excretion of 1-phenoxy-2-propanol in rats. Xenobiotica 33: 1059-1071

Schoettger RA, Steucke EW 1970: Synergic mixtures of MS-222 and quinaldine as anaesthetics for rainbow trout and northern pike. Prog Fish Culturist 32: 202-205

Sehedev HS, McBride JR, Fagerlund UHM 1963: 2-phenoxyethanol as general anaesthetic for sockeye salmon. J Fish Res Bd Can 20: 1435-1440

Siwicki A 1984: New anaesthetic for fish. Aquaculture 38: 171-176

Smutná M, Vorlová L, Svobodová Z 2002: Pathobiochemistry of ammonia in the internal environment of fish (Review). Acta Vet Brno 71: 169-181

Stoskopf MK, Arnold J 1985: Metomidate anaesthesia of ornamental freshwater fish. International Association for Aquatic Animal Medicine, IAAAM, 16th annual conference and workshop, Tacoma, Washington, USA. pp 12-21

Svobodová Z, Pravda D, Paláčková J 1986: Unified methods of haematological examinations of fish. Methods No. 22. Research Institute of Fish Culture and Hydrobiology Vodňany

Thienpoint D, Niemegeers CJE 1965: R 7464 - a new potent anaesthetic in fish. International Zoo Yearbook 5: 202-205

Velíšek J, Svobodová Z 2004a: Anaesthesia of common carp (Cyprinus carpio L.) with 2-phenoxyethanol: Acute toxicity and effects on biochemical blood profile. Acta Vet Brno 73: 247-252

Velíšek J, Svobodová Z 2004b: Anaesthesia of rainbow trout (Oncorhynchus mykiss) with 2-phenoxyethanol: Acute toxicity and biochemical blood profile. Acta Vet Brno 73: 379-384

Velíšek J, Wlasow T, Gomulka P, Svobodová Z, Novotný L, Ziomek E 2006: Effects of clove oil anaesthesia on European catfish (Siluris glanis L.). Acta Vet Brno 75: 99-106

Velíšek J, Svobodová Z, Piačková V 2007a: Effects of 2-phenoxyethanol anaesthesia on haematological profile on commn carp (Cyprinus carpio) and rainbow trout (Oncorhynchus mykiss). Acta Vet Brno 76: 487-492

Velíšek J, Własow T, Gomułka P, Svobodová Z, Novotný L. 2007b: Effects of 2-phenoxyethanol anaesthesia on sheatfish (Silurus glanis L.). Vet Med Czech 52: 103-110

Velíšek J, Stejskal V, Kouřil J, Svobodová Z 2009: Comparison of the effects of four anaesthetics on biochemical blood profiles of perch. Aquaculture Research 40: 354-361

Velíšek J, Stara A, Li ZH, Silovska S, Turek J 2011: Comparison of the effects of four anaesthetics on blond biochemical profiles and oxidative stress biomarkers in rainbow trout. Aquaculture 310: 369-375

Weber RA, Peleteiro JB, Garcia Martin LO, Aldegunde M 2009: The efficacy of 2-phenoxyethanol, metomidate, clove oil and MS-222 as anaesthetic agents in the Senegalese sole (Solea senegalensis Kaup 1858). Aquaculture 288: $147-150$

Wedemayer G 1970: Stress of anesthesia with MS-222 and benzocaine in rainbow trout, Salmo gairdneri. J Fish Res Bd Canada 27: 909-914

Wedemeyer GA, Gould RW, Yasutake WT 1983: Some potentials and limits of the 1 eucorit test as a fish health assessment method. J Fish Biol 23: 711-716

Wyets FAA, Flikt G, Verburg van Kemenade BML 1998: Cortisol inhibits apoptosis in carp neutrophilic granulocytes. Dev Comp Immunol 22: 563-572

Wyeth RC, Willows AOD 2006: Odours detected by rhinophores mediate orientation to flow in the nudibranch mollusk, Tritonia diomedea. J Exp Biol 209: 1441-1453 